\title{
Detection of a distinct gill-surface antibody response following horizontal infection and bath challenge of brook trout Salvelinus fontinalis with Flavobacterium branchiophilum, the causative agent of bacterial gill disease
}

\author{
J. S. Lumsden, V. E. Ostland, P. J. Byrne, H. W. Ferguson \\ Fish Pathology Laboratory, Department of Pathology, Ontario Veterinary College, University of Guelph, Guelph, Ontario,
} Canada N1G 2W1

\begin{abstract}
Gill mucus and serum were collected from 2-yr-old brook trout throughout the course of an experimental infection with bacterial gill disease (BGD). This was produced initially by horizontal transmission from sick rainbow trout fry, and secondly by bath challenge using a pure culture of the bacterium Flavobacterium branchiophilum. Increased serum and gill antibody levels were detected (in an indirect enzyme immunoassay to $F$, branchiophilum soluble antigen) following both horizontal transmission and bath challenge, although only the increase in gill antibody levels following bath challenge was statistically significant $(p<0.01)$. Maximum gill antibody levels took longer to reach (57 vs 16 d) during the secondary antibody response. Regression of individual gill antibody titres was poorly correlated with serum antibody titres in the same individuals $\left(r^{2}=0.012\right)$.
\end{abstract}

\section{INTRODUCTION}

The existence of a mucosal antibody response in teleosts has been widely proposed (Labb \& Clem 1981a). Effective vaccination for many fish diseases, particularly mucosal diseases, will require an understanding of the mucosal antibody response. Several studies have investigated the antibody responses of the skin (Ourth 1980, Lobb \& Clem 1981a, b, St. Louis-Cormier et al. 1984), of the intestine (Georgopoulou \& Vernier 1986, Rombout et al. 1989) and of bile (Lobb \& Clem 1981a, c). In most instances, specific mucosal antibody has been detected following parenteral immunization or 'local' exposure (Ourth 1980, Lobb 1987). In addition, exposure to antigen has been shown to stimulate an antibody response at more than one mucosal site (Rombout et al. 1986), as well as systemically, supporting the concept of a common mucosal immune system. The relationship between the mucosal and systemic responses is complex, however, because in some cases only one type of response is detectable (Fryer et al. 1976, Ward et al. 1985, Lobb 1987, Sakai et al. 1989,
Velji et al. 1991). In some teleosts it appears that the species of mucosal antibody may be structurally distinct from systemic antibody, although antigenically similar (Lobb \& Clem 1981a, b). There is also evidence that mucosal antibody is not due to serum transudation but that it results from local production (Lobb \& Clem 1981c, St. Louis-Cormier et al. 1984)

The gill is thought to be the major site of antigen uptake following immersion vaccination (Alexander et al. 1982, Smith 1982). The gill is also thought to be the route of infection for a variety of pathogens such as infectious hematopoietic necrosis (IHN) virus (Chilmonczyk \& Monge 1980), but there is little information describing the presence of antibody, specific or nonspecific, on or within the gill. This preliminary report describes the detection of a specific gill antibody response to a Flavobacterium branchiophilum-like organism. This organism has been identified as the cause of bacterial gill disease (BGD) in Ontario, Canada (Ferguson et al. 1991, V. E. Ostland unpubl.). For the purposes of this report the organism will be referred to as Flavobacterium branchiophilum. 


\section{MATERIALS AND METHODS}

Trout. Two-year-old brook trout Salvelinus fontinalis were held in 1001 circular fibreglass tanks supplied with water on a flow-through basis at $11{ }^{\circ} \mathrm{C}$; they were fed a commercial trout pellet ad libitum.

Experimental protocol. The first experimental sample was taken on Day $0,1 \mathrm{~d}$ before horizontal infection was initiated. The brook trout were then exposed to rainbow trout fry Oncorhynchus mykiss which were clinically ill with BGD. The previously healthy 2-yr-old brook trout were successfully infected and became clinically ill with heavy mortality (Ferguson et al. 1991). After $4 \mathrm{~d}$, the fish were treated with $10 \mathrm{ppm}$ chloramine- $\mathrm{T}$, which eliminated mortality. The surviving fish were then sampled at intervals, and the serum and gill antibody levels determined. After the gill immunoglobulin titres had fallen to approximately original levels (pre-horizontal transmission) the remaining 15 fish were bath-challenged (Day 200) with the Flavobacterium branchiophilum isolate recovered from the sick brook trout. Collection of individual serum and gill mucus samples then continued until no fish remained. Both serum and gill mucus were collected from at least 3 fish at each sample time.

Experimental challenge. Flavobacterium branchiophilum was grown in baffled culture flasks at $200 \mathrm{rpm}$ at $20^{\circ} \mathrm{C}$ for $48 \mathrm{~h}$ in cytophaga broth (Anacker \& Ordal 1959). Challenge of fish was carried out as described previously (Ferguson et al. 1991). Briefly, the 15 remaining brook trout were exposed to $1 \times 10^{6}$ organisms of a low passage isolate $(2 \times)$ of $F$. branchiophilum per $\mathrm{ml}$ of tank water for $45 \mathrm{~min}$ with heavy aeration before the water flow was turned back on. This challenge was designed to achieve infection without mortality by adding bacteria to a small number of fish in a large volume of water. In our experience stocking density is associated with severity of clinical signs and the development of mortality (unpubl. results). Clinical signs of bacterial gill disease, including coughing, and increased branchial movement abated 24 to $48 \mathrm{~h}$ after challenge.

Preparation of soluble antigen. Flavobacterium branchiophilum was grown in baffled culture flasks at $200 \mathrm{rpm}$ at $20^{\circ} \mathrm{C}$ for $48 \mathrm{~h}$ in cytophaga broth (Anacker \& Ordal 1959). The late log phase culture was centrifuged at $10000 \times \mathrm{g}$ for $30 \mathrm{~min}$ and the pellet resuspended in $10 \mathrm{ml}$ of $0.01 \mathrm{M}$ phosphate-buffered saline, $\mathrm{pH} 7.4$ (PBS). Following sonication on jce and recentrifugation as described, the supernatant was stored at $-20^{\circ} \mathrm{C}$ until use.

Mucus collection. Fish were euthanized with tricainemethanesulphonate (MS-222), pH 7.0. As much blood as possible was removed from the caudal vessel using a $20 \mathrm{~g}$ needle. The fish was then wrapped in paper towels to absorb any remaining moisture and skin mucus, thereby preventing contamination of the gill mucus during its collection. The caudal vessel was then cut allowing exsanguination, after which the heart was exposed and the caudal vena cava detached from the sinus venosus. The gills were directly perfused with heparinized saline by puncture of the ventricle or bulbus arteriosus with a 26 g needle. Perfusion was continued until the gills were completely blanched (approximately $30 \mathrm{~s}$ ). One gill arch was collected for histological examination. The remaining gill arches were excised and soaked in a cocktail consisting of $0.85 \%$ saline, $2 \mathrm{mM}$ phenylmethlysulphonylfluoride (PMSF), $2 \mathrm{mM}$ N-ethylmalemide (NEM), $10 \mathrm{mM}$ disodium ethylenediamine tetraacetate (EDTA), and $0.02 \%$ sodium azide $\left(\mathrm{NaN}_{3}\right)$ for $2 \mathrm{~h}$ at $4{ }^{\circ} \mathrm{C}$, with occasional shaking (PMSF was included not only because it is an antiprotease, but because it degrades mucosa). Gill mucus collections were observed to be free from red blood cells before centrifugation. The collected mucus preparations were centrifuged at $30000 \times g$ for $30 \mathrm{~min}$ at $4^{\circ} \mathrm{C}$, and the resulting supernatants were dialysed against distilled-deionized water $\left(\mathrm{ddH}_{2} \mathrm{O}\right)$ containing PMSF and $\mathrm{NaN}_{3}$. Dialysate was centrifuged at $1000 \times g$ for $15 \mathrm{~min}$ to remove any additional debris. The crude gill mucus (CGM) was then lyophilized until used. Each individual sample was resuspended in $1 \mathrm{mI}$ of PBS with $\mathrm{NaN}_{3}$ for enzyme immunoassay (EIA). To determine if differences in gill weight would influence the gill immunoglobulin results the optical density (O.D.) value of $\log _{2} 1$ and $\log _{2} 2$ dilutions of each CGM sample was multiplied by the inverse weight of the wet gill sample.

Preparation of rabbit anti-rainbow-trout serum immunoglobulin (RaRTSIg). Rainbow trout serum immunoglobulin was purified as described (Havarstein et al. 1988). Two female New Zealand White rabbits were injected subcutaneously 3 times with $500 \mu \mathrm{g}$ of purified RTSIg mixed 1:1 with Freund's incomplete adjuvant. The rabbits were exsanguinated $1 \mathrm{wk}$ after the third injection.

Biotinylation of the rainbow trout serum immunoglobulin (RaRTSIgB). The rabbit antiserum raised against rainbow trout serum immunoglobulin was precipitated with $50 \%$ ammonium sulphate and biotinylated (Harlow \& Lane 1988). Briefly, the pellet was dialysed against $0.1 \mathrm{M}$ sodium borate $\mathrm{pH} 8.8$, and $10 \mathrm{mg}$ (bicinchoninic acid assay) was added to $40 \mu \mathrm{l}$ of a $50 \mathrm{mg} \mathrm{ml}^{-1}$ solution of Biotin [amidocaproate ( $\mathrm{N}$ hydroxysuccinaamide ester)] (Sigma, St. Louis, MO, USA) stock in dimethylsulfoxide. After incubation at room temperature (RT) for $2 \mathrm{~h}, 160 \mu \mathrm{l}$ of $1 \mathrm{M}$ ammonium chloride was added and the product was extensively dialysed against PBS with $0.02 \% \mathrm{NaN}_{3}$ and stored at $-20^{\circ} \mathrm{C}$ 
Immunoelectrophoresis. This was performed as previously described (Rose et al. 1986). Individual serum samples and gill mucus washings were added undiluted and reacted with RaRTSIg serum.

Enzyme immunoassay. CGM and serum samples were assayed from individual fish. The indirect EIA was performed with soluble Flavobacterium branchiophilum antigen prepared as described. Soluble antigen was diluted in coating buffer $(15 \mathrm{mM}$ sodium carbonate, $34 \mathrm{mM}$ sodium bicarbonate, $0.02 \% \mathrm{NaN}_{3}, \mathrm{pH}$ 9.6), and incubated overnight at RT in Immulon 96 well microtitre plates (Dynatech, Chantilly, VA, USA) at a concentration of $1 \mu \mathrm{g}$ well ${ }^{-1}$. Plates were washed 5 times with $0.05 \% \mathrm{v} / \mathrm{v}$ Tween 20 in PBS (PBS/Tween). One hundred $\mu$ l of doubling dilutions of CGM or serum were incubated for $1 \mathrm{~h}$ at RT. Washing was repeated and RaRTSIgB immunoglobulin diluted 1:1000 in PBS/Tween was added for $1 \mathrm{~h}$ at RT. Following washing, a 1:1000 dilution of Extravidin-peroxidase (Sigma) was added for $1 \mathrm{~h}$ at RT, after which washing was repeated and substrate $\left\{\left(2,2^{\prime}\right.\right.$-azino-di[3-ethylbenzthiazoline sulfonate(6)]\}, (Kirkegaard Perry Laboratories, Gaithersburg, MD, USA) was added. Plates were read at 405 and $540 \mathrm{~nm}$ (540 subtracted from 405) (BIO-TEK microplate autoreader, Model EL311, BIO-TEK Instruments Inc., Winooski, VT, USA). The positive control serum pool which was used as the reference serum was from 4 brook trout which were hyperimmunized by 7 intraperitoneal injections with whole formalin-killed $F$ branchiophilum mixed 1:1 with Freund's incomplete adjuvant. The negative control serum pool was from the experimental brook trout before the transmission of BGD (Day 0 sample). The reported titre of individual serum and gill samples was the highest dilution which gave an O.D. value greater than the mean plus 2 standard deviations of the O.D. value of $\log _{2} 1$ dilution of the negative control serum samples.

ElA cross-reactivity was determined by coating wells with $1 \mu \mathrm{g}$ of soluble antigen prepared (as described) from the following organisms: ATCC 17061 and 29583, Cytophaga johnsonae; ATCC E11947, Flavobacterium aquatile; ATCC 23079-1, Flexibacter flexilis; ATCC 19366, C. pectinovora; and ATCC 30035 and 35036 Flavobacterium branchiophilum.

Histology. Perfused gill arches were placed in Bouin's fixative for $24 \mathrm{~h}$ and then in $70 \%$ ethanol. Arches were processed for routine paraffin wax embedding and sectioning. Sections were stained with hematoxylin and eosin.

Protein assay. Protein content was determined by the bicinchoninic acid technique (Pierce, Rockford, IL, USA).

Statistical analysis. Data were analysed using a Fisher's exact test. A Fisher's protected least squares difference was performed because of the nature of the experimental protocol which it was necessary to adopt in this study. Specifically, a post-hoc analysis was used because, with the limited number of fish available, sampling times were random and could not be planned in advance. Because the approximate time course of an antibody response could be estimated, this was used as general guideline for sampling. The limited number of fish at the start of the experiment also resulted in a smaller sample size than would be desirable. This was especially true considering the variability of antibody response among individual fish, a phenomenon which has been widely reported (Dunier 1985). As well, sampling of gill mucus was obviously a terminal event, and this also increased the inherent variability in the experiment. If simple $t$-tests are used to analyse the differences between means then many more become significantly different. In this experiment such analysis was not applicable because the possibility of missed peak values was obvious.

\section{RESULTS}

Horizontal transmission of BGD to the adult brook trout showed bacteria adhering to their gills $24 \mathrm{~h}$ after addition of the infected rainbow trout (Ferguson et al. 1991). The presence of filamentous bacteria was associated with clinical signs of reduced fright response, lack of feed response, flared opercula, tachybranchia, and coughing. Mortality began 72 h after co-habitation, with $100 \%$ morbidity and very high mortality rates. By the fourth day of co-habitation, mortality was so severe that all remaining fish were treated with chloramine- $\mathrm{T}$ at $10 \mathrm{ppm}$ for $1 \mathrm{~h}$, after which mortality ceased.

Challenge infection with the bacteria alone resulted in clinical signs similar to those seen following horizontal transmission, except that the signs were evident by 1 to $2 \mathrm{~h}$ following challenge (Ferguson et al. 1991). Clinical signs were again associated with the presence of adherent filamentous bacteria on the gills.

The RaRTSIg antiserum was specific for both rainbow trout and brook trout serum immunoglobulin and also produced a precipitin band with similar mobility (slightly anodal) to brook trout serum immunoglobulin in the CGM (Fig. 1). The EIA assay produced significant cross-reactions with the 2 reference Flavobacterium branchiophilum strains only (not shown).

Differences in serum antibody levels were not significant at any time. The absolute differences between Day 0 and Day 26, and Day 180 and Day 258 are clear. These increases in serum antibody following horizontal transmission and after challenge were of similar magnitude (Fig. 2). Gill antibody levels at Days 223 


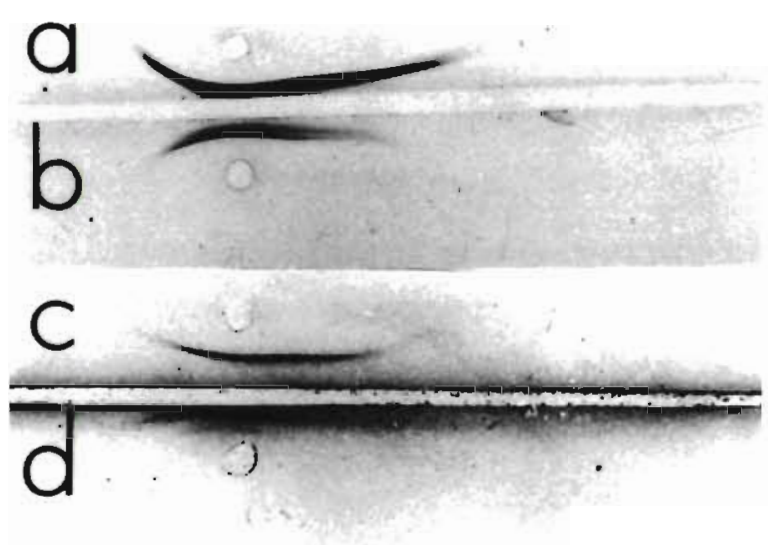

Fig. 1 Immunoelectrophoresis plate showing precipitin arcs produced by the rabbit anti-rainbow-trout serum immunoglobulin. (a) Rainbow trout Oncorhynchus mykiss serum undiluted. (b, c) Brook trout Salvelinus fontinalis serum undiluted. (d) Brook trout CGM from a single fish. The letters are toward the anode

and 258 were significantly higher than those at all other sample times $(p<0.01)$. The peak following horizontal transmission on Day 17 was not significantly different from the pre-infection sample mean. The rise in

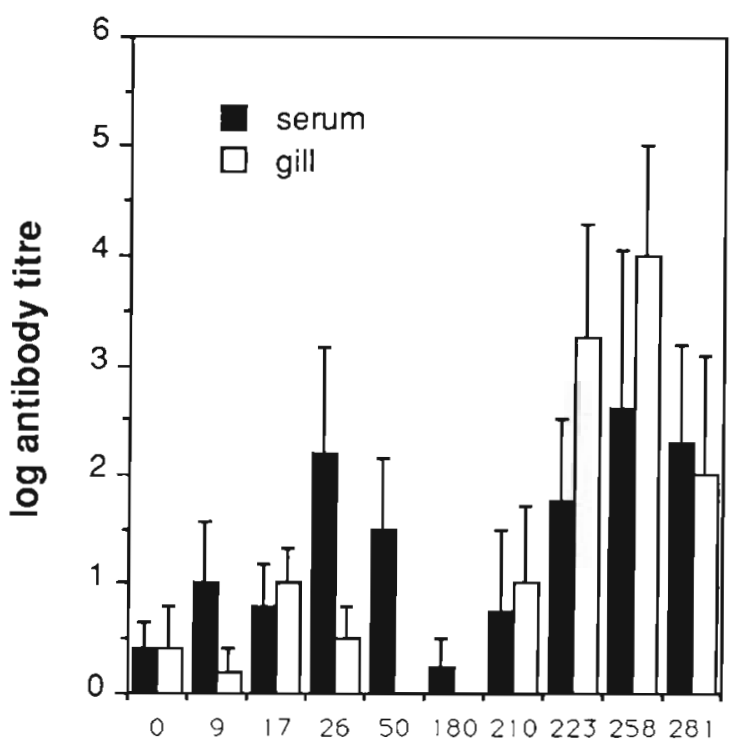

\section{day}

Fig. 2. Serum antibody (solid bar) and gill antibody titres (open bar) to Flavobacterium branchiophilum soluble antigen, following horizontal infection (Day 1) and bath challenge (Day 200) with F branchiophilum. The titre is expressed as the highest doubling dilution with an O.D. reading higher than the $\log _{2} 1$ dilution of the pooled negative serum samples plus 2 standard deviations gill antibody after experimental challenge is clearly higher than after horizontal challenge although it took longer to reach peak levels (16 vs 57 d) (Fig. 2). Mean serum antibody titres were not significantly different from the mean gill antibody titres at any sample time. However, regression of individual gill antibody levels with or without adjustment for gill weight were poorly correlated with serum antibody levels in the same individuals, $\left(\mathrm{r}^{2}=0.160\right.$ and 0.012 , respectively $)$. Adjustment of O.D. readings for gill weight did not significantly change the gill immunoglobulin results (not shown).

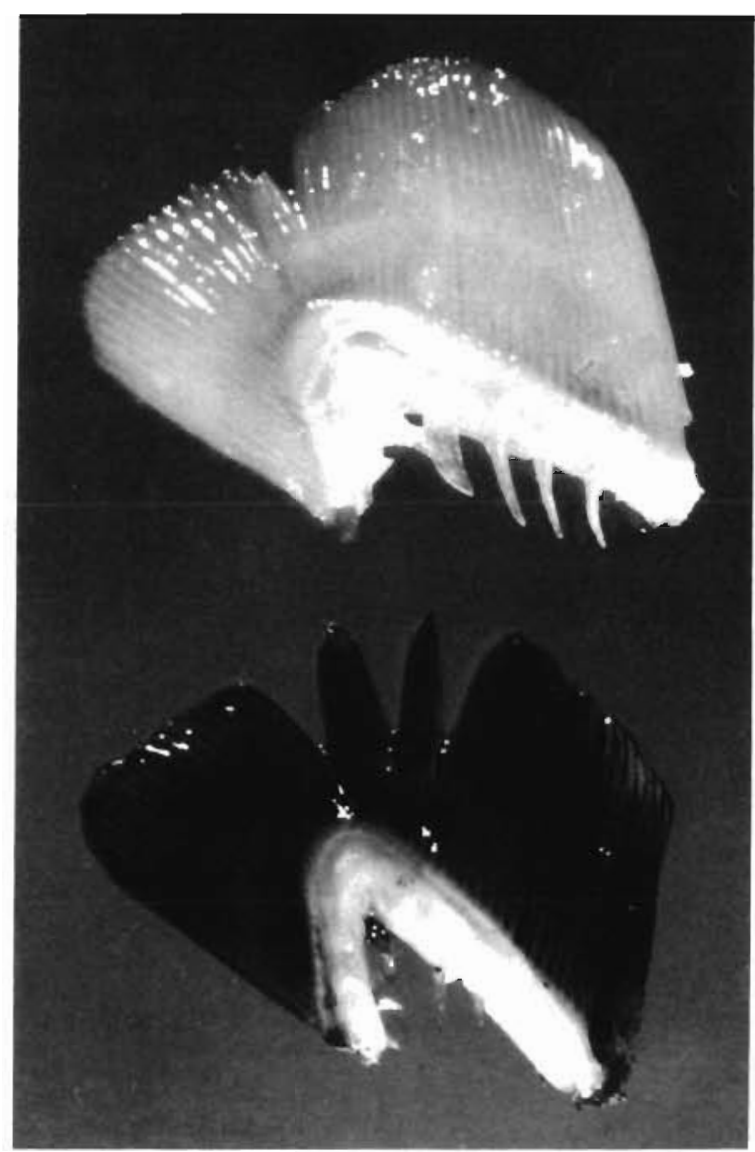

Fig. 3. Salvelinus fontinalis. Gross view of a gill arch excised from a fish which had been perfused with saline (top), compared to a gill arch excised from a non-perfused fish (bottom).

Note the complete pallor of the perfused gill arch

Grossly, perfused gills were extremely pale (Fig. 3). Histologically the gills showed virtually complete removal of red blood cells, distension of the marginal channel, mild epithelial lifting (Fig. 4), and no evidence of vascular rupture. Histology also showed that the gills were severely degraded after incubation in gill collection cocktail, indicating invasive collection (not shown). 


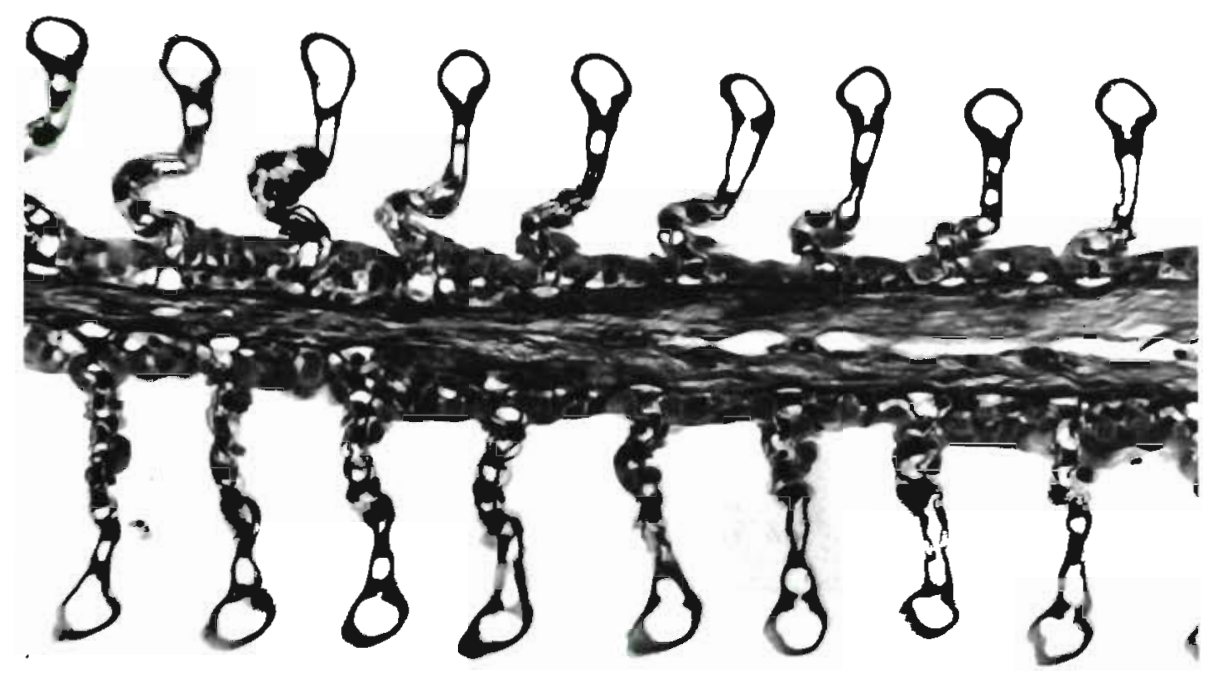

Fig. 4. Salvelinus fontinalis. Histological section of a gill arch excised from a saline perfused fish and immediately fixed in $10 \%$ buffered formalin. Note the distension of the marginal channel, occasional lifting of the outermost epithelial cell layer and necrosis of the pillar cells

\section{DISCUSSION}

Two lines of evidence support the existence of a specific, inducible gill antibody response which was independent of systemic antibody production. Firstly, the mean and individual gill antibody titres were often higher than the corresponding serum antibody titres. Secondly, regression analysis of gill and serum antibody levels revealed that the 2 parameters were poorly correlated. In other words, high specific serum antibody levels did not correlate with high specific gill antibody levels in the same fish. This was true whether or not the gill antibody data were adjusted for gill weight.

Mucosal immunity in teleosts has not received the degree of study needed to answer many basic questions. This is unfortunate because mucosae are probably the route of infection for all horizontally transmitted fish pathogens (Chilmoncyzk \& Monge 1980, Kanno et al. 1989, LaPatra et al. 1989). In addition, vaccination of mucosae likely preferentially stimulates a mucosal immune response as well as a systemic response, with the quality of the systemic response depending on the nature of the antigen(s), their dose, and their route of presentation (Lobb 1987, Rombout et al. 1989)

Stimulating the production of good systemic antibody responses by parenteral immunization is the basis of protection following vaccination for Vibrio spp. in teleosts (Harrell et al. 1976, Velji et al. 1991). These organisms are systemic, extracellular pathogens for which systemic antibody, stimulated by bacterins, is protective. Nevertheless, protection induced by bath vaccination for these organisms is likely due not only to systemic antibody production, but also to the stimulation of antibody at the mucosal surface which is the site(s) of infection (Gould et al. 1975, Ward et al. 1985). For the gill pathogen Flavobacterium branchiophilum the most logical protective immune response would be a local gill antibody response capable of agglutinating and/or blocking antigens on the gill surface.

Secondary exposure to Flavobacterium branchiophilum stimulated a serum antibody response with primary characteristics. There was no significant difference in the maximum serum antibody titres following primary or secondary stimulation. The absence of a secondary antibody response has been noted previously in rainbow trout (Dunier 1985). Local exposure to antigen has been shown to stimulate a variable systemic antibody response in teleosts (Ward et al. 1985, Lobb 1987). It is clear in this experiment that local exposure stimulated systemic antibody production but that secondary exposure did not prime the systemic immune system for an anamnestic response. In addition, primary and secondary specific serum titres were low, especially when compared to the titre of the positive control serum $\left(\log _{2} 10\right)$. Systemic antibody is possibly less important for protection from BGD in any case, because the organism appears to be primarily a gill pathogen, without systemic invasion (Speare et al. 1991a). Systemic antibody may play a role, however, if gill surface antibody is partially derived from serum transudation, as has been proposed for antibody on other mucosal surfaces (Harrell et al. 1976, Ourth 1980), or if gill damage is associated with BGD (Speare et al. 1991a, b), allowing pathotopic potentiation. 
In most situations in Ontario, BGD is normally an acute disease of young fish (Speare \& Ferguson 1989). Accordingly, the importance of an anamnestic gill antibody response for resistance to Flavobacterium branchiophilum during an acute outbreak is questionable. After exposure to the organism, BGD has been shown to develop quickly (within $48 \mathrm{~h}$ ), with severe mortality occurring in a similar time frame (less than $3 \mathrm{~d}$ even in very large fish). Therefore the development of increased antibody levels within $1 \mathrm{wk}$ for example, instead of 3, would be of little consequence to infected fish. Of much more importance, especially considering disease prevention, is the length of time after immunization that increased levels of antibody are present on the surface of the gill. In this sense, the gill exhibited a significant increase in response following seconday exposure, with increased levels of specific antibody detectable for at least $2 \frac{1}{2}$ mo compared with 1 mo after the initial exposure. However, the possibility exists that treatment with chloramine-T somehow blocked the development of a good primary gill antibody response (therefore giving the appearance of an 'anamnestic' gill antibody response), although there is no information in the literature to support this.

Assuming that the presence of specific antibody on the surface of the gill would provide protection from infection, then vaccination of fish for the prevention of gill disease may be possible. The clinical observation that fish which have survived an outbreak of bacterial gill disease can become reinfected and die during a subsequent outbreak or experimental challenge (Heo et al. 1990) does not necessarily negate the possible protective effect of a gill surface antibody response. If 'immune' fish were exposed to BGD organisms during the period of low specific gill antibody levels then the infection would not be blocked and disease could progress. Therefore, the critical component of the gill response is likely the stimulation of long-lasting antibody production (a wide peak). Two aspects which clearly need to be investigated for optimal stimulation of the gill antibody response are the dose of the stimulating antigen(s), and the number of primer immunizations needed to stimulate an adequate period of protection. Stimulation of mucosal antibody responses with strong memory often requires multiple vaccinations delivered by the proper route (Ganguly \& Waldman 1983); nevertheless, if the gill antibody response (or other mucosal response) is critical for protection, then more frequent immunizations may be worthwhile.

The levels of specific gill antibody detectable were often higher than serum levels but because of the high variability and low sample number the differences are not significant. These results do not agree with the re- sults of others who have found that the relative concentration of mucosal immunoglobulin was very low (Lobb \& Clem 1981a) compared to serum immunoglobulin. Production of an immunoglobulin response from an everted organ such as the gill would be pointless, however, unless there was a mechanism for maintenance of antibody within the gill mucus layer and therefore on the surface of the gill. Such a mechanism has been proposed for mammalian systems (Magnusson \& Stjernstrom 1982).

Acknowledgements. The Fish Pathology Laboratory receives much of its funding from the Ontario Ministry of Agriculture. J.S.L. is funded through a Fellowship from the Medical Research Council of Canada.

\section{LITERATURE CITED}

Alexander, J. B., Bowers, A., Ingram, G. A., Shamshoon, S. M. (1982). The portal of entry of bacteria into fish during hyperosmotic infiltration and the fate of antigens. Dev. Comp. Immunol. Suppl. 2: 41-46

Anacker, R. L., Ordal, E. J. (1959). Studies on the myxobacterium Chondrococcus columnaris. I. Serological typing. J. Bacteriol. 78: 25-32

Chilmonczyk, S., Monge, D. (1980). Rainbow trout pillar cells: demonstration of inert particle phagocytosis and involvement in viral infection. $J$ Reticuloend. Soc. 28(4): $327-332$

Dunier, M. (1985). Absence of antibody reponse to DNP-haemocyanin and DNP-ficoll in rainbow trout. In: Manning, M. J., Tatner, M. F. (eds.) Fish immunology. Academic Press, London, p. 171-184

Ferguson, H. W., Ostland, V. E., Byrne, P., Lumsden, J. S. (1991). Experimental production of bacterial gill disease in trout by horizontal transmission and by bath challenge. J. aquat. Anim. Health. 3: 118-123

Fryer, J. L., Rohovec, J. S., Tebbit, G. L., McMichael, J. S., Pilcher, K. S. (1976). Vaccination for the control of infectious diseases in Pacific salmon. Fish Path. 19: $155-164$

Ganguly, R., Waldman, R. H. (1983). T-cell and B-cell memory on mucosal surfaces. In: The secretory immune system. Ann. N. Y. Acad. Sci., Vol. 409, p. 603,-611

Georgopoulou, U., Vernier, J. (1986). Local immunological response in the posterior segment of the rainbow trout after oral administration of macromolecules. Dev. Comp. Immunol. 10: 529-537

Gould, R. W., O'Leary, P. J., Garrison, R. L., Rohovec, J. S. Fryer, J. L., Harrell, L. W., Etlinger, H. M., Hodgins, H. O. (1975). Humoral factors important in resistance of salmonid fish to bacterial disease. I. Serum antibody protection of rainbow trout (Salmo gairdneri) against vibriosis. Aquaculture 6: 211-220

Harlow, E., Lane, D. P. (1988). Antibodies, a laboratory manual. Cold Spring Harbor Laboratory, Cold Spring Harbor, NY, p. 341

Harrell, L. W., Etlinger, H. M., Fryer, H. O. (1976). Humoral factors important in resistance of salmonid fish to bacterial disease. II. Anti-Vibrio anguillarum activity in mucus and observations on complement. Aquaculture 7: 363-370

Havarstein, L. S., Aasjord, P. M. Ness, S., Endresen, C. (1988). Purification and partial characterization of an IgM-like 
serum immunoglobulin from Atlantic salmon (Salmo salar). Dev. Comp. Immunol. 12(4): 773-785

Heo, G., Kazuhiko, K., Wakabyashi, H. (1990). Occurrence of Flavobacterium branchiophila associated with bacterial gill disease at a trout hatchery. Fish Path. 25: 99-105

Kanno, T., Nakai, T., Muroga, K. (1989). Mode of transmission of vibriosis among ayu Plecoglossus altivelis $\mathrm{J}$. aquat Anim. Health 6: 2-6

LaPatra, S. E., Rohovec, J. S., Fryer, J. L. (1989). Detection of infectious hematopoetic necrosis virus in fish mucus. Fish Path. 24(4): 197-202

Lobb, C. J. (1987). Secretory immunity induced in catfish, Ictalurus punctatus, following bath immunization. Dev Comp. Immunol. 11: 727-738

Lobb, C. J., Clem, L. W. (1981a). The metabolic relationships of the immunoglobulins in fish serum, cutaneous mucus and bile. J. Immunol. 127(4): 1525-1529

Lobb, C. J., Clem, L. W. (1981b). Phylogeny of immunoglobulin structure and function. XI. Secretory immunoglobulins in the cutaneous mucus of the sheepshead. Archosargus probatocephalus. Dev. Comp. Immunol. 5: 587-596

Lobb, C. J., Clem, L. W. (1981c). Phylogeny of immunoglobulin structure and function. XII. Secretory immunoglobulins in the bile of the marine teleost Archosargus probatocephalus. Mol. Immunol. 18(7): 615-619

Magnusson, K. E., Stjernstrom, I. (1982). Mucosal barrier mechanisms. Interplay between secretory $\lg \mathrm{A}$ (SIgA), $\lg G$ and mucins on the surface properties and association of salmonellae with intestine and granulocytes. Immunology 45: $239-248$

Ourth, D. D. (1980). Secretory IgM, lysozyme and lymphocytes in the skin mucus of the channel catfish, Ictalurus punctatus. Dev. Comp. Immunol. 4: 65-74

Rombout, J. H. W. M., Blok, L. J., Lamers, C. H. J., Egberts, E (1986). Immunization of carp (Cyprinus carpio), with a Vibrio anguillarum bacterin: indications for a common mucosal immune system. Dev. Comp. Immunol. 10: $341-351$

Rombout, J. H. W. M., van den Burg, A. A., van den Burg, C. T. G. A., Witte, P., Egberts, E. (1989). Immunological im-

Responsible Subject Editor: T. Evelyn, Nanaimo, B.C., Canada portance of the second gut segment of carp. III. Systemic and/or mucosal immune responses after immunization with soluble or particulate antigen. J. Fish Biol. 35: $179-186$

Rose, N. R., Freidman, H., Fahey, J. L. (eds.) (1986). Manual of clinical laboratory immunology, 3rd edn. American Society of Microbiology, Washington, DC

Sakai, M., Atsuta, S., Kobayashi, M. (1989). Protective immune response in rainbow trout, Oncorhynchus mykiss, vaccinated with $B$-haemolytic streptococcal bacterin. Fish Path. 24(3): 169-173

Smith, P. D. (1982). Analysis of the hyperosmotic and bath methods for fish vaccination - comparison of uptake of particulate and non-particulate antigens. Dev. Comp. Immunol. Suppl. 2: 181-186

Speare, D. J., Ferguson, H. W. (1989). Clinical and pathological features of common gill diseases of cultured salmonids in Ontario. Can. vet. J. 30: 882-887

Speare, D. J., Ferguson, H. W., Beamish, F. M. W., Yager, J. A., Yamashiro, S. (1991a). Pathology of bacterial gill disease: ultrastructure of branchial lesions. J. Fish Dis. 14: $1-20$

Speare, D. J., Ferguson, H. W., Beamish, F. M. W., Yager, J. A., Yamashiro, S. (1991b). Pathology of bacterial gill disease: sequential development of lesions during natural outbreaks of disease. J. Fish Dis. 14: 21-32

St. Louis-Cormier, E. A., Osterland, C. K., Anderson, P. D. (1984). Evidence for a cutaneous secretory immune system in rainbow trout (Salmo gairdneri). Dev. Comp. Immunol. 8: $71-80$

Velji, M. I., Evelyn, T. P. T., Albright, L. J. (1991). Nature of the immune response in coho salmon Oncorhynchus kisutch following vaccination with Vibrio ordalii lipopolysaccharide by two different routes. Dis. aquat. Org. 11: 79-84

Ward, P. D., Tatner, M. F., Horne, M. T (1985). Factors influencing the efficacy of vaccines against vibriosis caused by Vibrio anguillarum. In: Manning, M. J., Tatner, M. F. (eds.) Fish immunology. Academic Press, London, p. $221-229$

Manuscript first received: November 28, 1991

Revised version accepted: February 3, 1993 